\title{
Sodium Glucose Co-Transporter 2 (SGLT2) 억제제
}

\author{
인제대학교 의과대학 내과학교실, 백인제기념임상의학연구소
}

김미경 · 박정현

\section{Sodium Glucose Co-Transporter 2 (SGLT2) Inhibitor}

\author{
Mi-kyung Kim and Jeong Hyun Park \\ Paik Institute for Clinical Research, Department of Internal Medicine, Inje University College of Medicine, Busan, Korea
}

Sodium glucose co-transporter 2 (SGLT2) inhibition is a new therapeutic approach for the treatment of type 2 diabetes mellitus, independent of insulin secretion and activity. SGLT2 inhibitors have a unique mechanism of action via inhibition of renal glucose reabsorption, which is different from the mechanisms of prior medications. Clinical trials have supported the efficacy of SGLT2 inhibitors in the reduction of $\mathrm{HbAlc}$ as monotherapy or add-on therapy with other existing medications, including insulin. In addition to their glucose-lowering effect, SGLT2 inhibitors can significantly reduce blood pressure and body weight. The most concerning side effects are genital and urinary tract infections, especially in females. SGLT2 inhibitors offer a promising potential strategy for diabetes treatment because they can be combined with nearly any existing anti-diabetic medication, cause less hypoglycemia, and possess additional metabolic benefits beyond glucose level reduction. (Korean J Med 2014;87:14-18)

Keywords: Type 2 Diabetes; Renal glucose reabsorption;SGLT2 inhibitors; Urinary tract infection; Genital infection

서 론

당뇨병의 치료는 인슐린의 발견 이후 지난 90 여 년 동안 많은 발전을 하였고 특히 최근 20년 동안에는 더욱 다양한 혈당강하약제들이 소개되었다. 그러나 아직까지 당뇨병 환 자의 대사조절은 만족스럽지 못한 상태로, 대한당뇨병학회 의 자료에 의하면 당화혈색소 $7 \%$ 미만으로 조절이 되고 있 는 환자는 $43 \%$ 정도이다[1]. 제 2 형 당뇨병 역시 유병 기간이 경과할수록 인슐린을 분비하는 췌장의 베타세포 기능이 점
차 감퇴되기 때문에 여러 가지 약제를 조합해서 쓰더라도 혈당조절이 점점 되지 않고 종국에는 합병증의 발생을 피할 수 없는 진행성 질환이다. 현재 사용되고 있는 다양한 혈당 강하제들은 각각 장단점을 가지고 있지만 그 어느 약물도 혈당강하 능력과 부작용의 측면에서 완벽한 것은 없어서 여 전히 우리는 더 다양하고 효과적이며 부작용의 측면에서 더 안전한 당뇨병 치료제를 필요로 한다.

최근 제2형 당뇨병의 병태생리가 많이 밝혀지면서 새롭 게 주목받게 된 것 중의 하나가 당뇨병에서 신장의 역할이

Correspondence to Jeong Hyun Park, M.D., Ph.D.

Paik Institute for Clinical Research, Department of Internal Medicine, Pusan Paik Hospital, Inje University College of Medicine, 75 Bokji-ro, Busanjin-gu, Busan 614-735, Korea

Tel: +82-51-890-6074, Fax: +82-51-892-0273, E-mail: pjhdoc@chol.com 
- Mi-kyung Kim, et al. Sodium glucose co-transporter 2 (SGLT2) inhibitor -

다. 이와 함께 신장에서 포도당 재흡수에 관여하는 sodium glucose co-transporter 2 (SGLT2) 억제제가 개발되어 더욱 큰 관심을 받게 되었으므로 신장이 정상적으로 포도당 항상성 에 미치는 영향 및 당뇨병 상태에서의 변화, SGLT2 억제제 의 효과 및 부작용 등에 대한 간략히 살펴보기로 한다.

\section{신장이 정상적인 포도당 항상성(glucose homeostasis)에 미치는 영향}

신장은 세 가지의 각기 다른 방식으로 혈액 속 포도당 농 도를 일정하게 유지하는 데 기여하게 된다. 그 세 가지 기전은 포도당을 생합성하여 혈액 속으로 내보내고(gluconeogenesis), 혈액 속 포도당을 신장에서 에너지로 이용(glucose utilization) 하며, 사구체에서 여과된 포도당을 재흡수(glucose reabsorption)하는 것이다.

\section{신장의 포도당 생성(renal gluconeogenesis)}

약 14-16시간 동안 공복 상태가 지속되면 인체에서 필요 한 포도당량의 절반은 간에서 glycogen을 분해해서 생성되 고 나머지 반은 간과 신장에서 새로운 포도당 생성 즉 gluconeogenesis를 통해 충당된다[2]. 식사 후에는 우리 몸에서 새 롭게 생성하는 포도당의 양은 급격하게 줄어들게 되어 간에 서 혈액 속으로 유리되는 포도당은 거의 없게 된다. 그러나 신장에서는 식후에 오히려 포도당 신생작용이 2 배로 증가되 게 되는데 이것은 아마도 간에서 글리코겐 저장을 효과적으 로 하게 하기 위함일 것으로 설명되고 있다[3]. 호르몬의 영 향을 살펴보면 인슐린은 간과 신장 모두에서 포도당 생성을 억제시키지만 글루카곤은 간에서만 포도당 유리를 증가시킨 다. 카테콜라민이 신장의 포도당 생성에 직접적인 역할을 하 고[4] 코티졸, 성장호르몬과 갑상선호르몬이 신장 포도당 생 성에 미치는 영향은 사람에게서는 아직 확실하지 않다.

\section{신장의 포도당 이용(renal glucose utilization)}

공복 상태에서 신장은 우리 몸의 포도당 중 대략 $10 \%$ 를 사용하게 된다. 식후에는 그 이용률이 3 배로 증가하게 되는 데 전체적으로는 포도당 이용에 있어서 신장의 역할은 그리 크지 않다[3].

\section{신장의 포도당 재흡수(renal glucose reabsorption)}

정상적으로 신장에서는 하루에 약 $180 \mathrm{~g}$ 정도의 포도당이 사구체를 통해 여과된다. 정상인에서는 여과된 거의 모든 포 도당이 재흡수되어 소변에서는 포도당이 검출되지 않는다. 포도당항상성에서는 재흡수에 관여하는 신장의 이 기능이 가장 중요하다. 재흡수는 근위세뇨관에 있는 sodium-glucose co-transporters (SGLT1과 SGLT2)가 주로 담당한다. SGLT는 여섯 종류가 현재까지 알려져 있고 여러 가지 장기에 분포 하고 있지만 아직 그 기능은 다 알려지지는 않았다(Table 1) [5]. 근위 세뇨관에서의 포도당 흡수는 신장에만 주로 발현되는 $\mathrm{SGLT} 2$ 가 $90 \%$ 를 담당하고 장관과 신장에 같이 발현되는 $\mathrm{SGLT} 1$ 이 $10 \%$ 를 담당한다고 알려져 있다. SGLT2나 SGLT1을 통해 재흡수된 포도당은 basolateral membrane에 있는 glucose transporters (GLUTs)를 통해 혈액 속으로 이동된다 (Fig. 1) [6]. 사구체를 통해 여과되는 포도당은 혈액 속 포도당 농도에 비례하여 늘어난다. 여과된 포도당의 재흡수는 정상인의 경 우 혈액 속 포도당 농도가 약 $200 \mathrm{mg} / \mathrm{dL}$ 가 될 때까지 늘어나 다가 그 이상이 되면 재흡수는 감소하고 소변에서 포도당이 검출되기 시작한다(Fig. 2) [7].

\section{당뇨병 상태에서 포도당항상성에 대한 신장의 역할 변화}

\section{신장의 포도당 생성(renal gluconeogenesis)}

당뇨병 상태에서는 공복 시 신장에서 혈액 속으로 유리되 는 포도당이 증가되어 그 양이 간에서 유리되는 것과 비슷 해진다. 식후에도 정상인보다 포도당 생성이 더 증가된다.

\section{신장의 포도당 이용(renal glucose utilization)}

공복 시 신장에서의 glucose uptake는 정상인에서보다 당뇨 병에서 더 증가되어 신장에서 증가되었던 포도당 생성을 능 가하게 된다. 식후에는 당뇨병 환자에서 신장에서의 glucose uptake는 2 배로 증가되지만 근육에서는 크게 변화하지 않는 다[8].

\section{신장의 포도당 재흡수(renal glucose reabsorption)}

정상인과 비교해서 당뇨병 환자에서 신세뇨관의 포도당 재흡수가 증가되어 있다고 알려져 있다. 정확한 기전은 아직 밝혀지지 않았지만 약물로 유도된 제2형 당뇨병 동물모델에서 정상이거나 내당능장애보다 당뇨병 모델의 신장에서 SGLT2 
Table 1. The sodium glucose co-transporter family

\begin{tabular}{llll}
\hline Co-transporter & Gene & Substrate & Tissue distribution \\
\hline SGLT1 & SLC5A1 & Glucose, galactose & Intestine, trachea, kidney, heart, brain, prostate \\
SGLT2 & SLC5A2 & Glucose & Kidney, brain, liver, thyroid, muscle, heart \\
SGLT4 & SLC5A9 & Glucose, mannose & Intestine, kidney, liver, brain, lung \\
SGLT5 & SLC5A10 & Not known & Kidney \\
SGLT6 & SMIT2/SLC5A11 & Glucose, myo-inositol & Brain, kidney, intestine \\
SMIT1 & SLC5A3 & Glucose, myo-inositol & Brain, heart, kidney, lung \\
\hline
\end{tabular}

SGLT, sodium-glucose co-transporter; SMIT, sodium-myoinositol transporter.

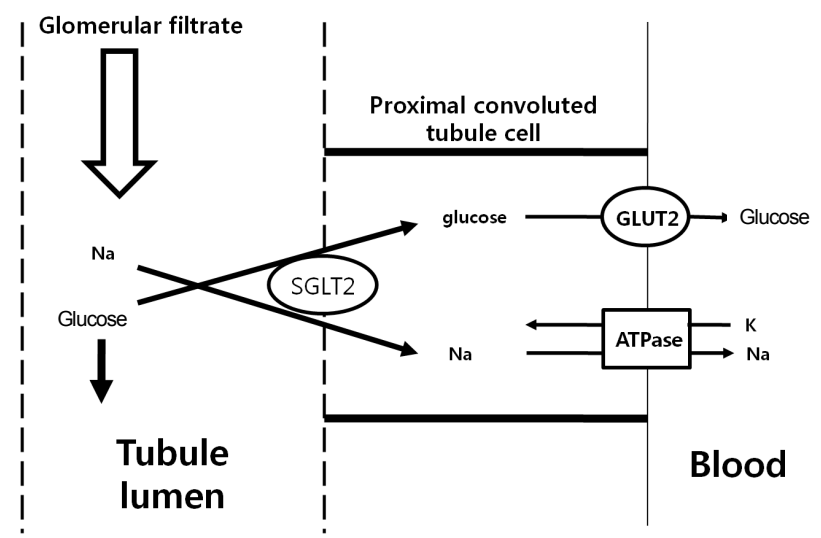

Figure 1. Glucose reabsorption from the glomerular filtrate through a proximal tubular epithelial cell into the blood. GLUT, glucose transporter; SGLT, sodium-glucose co-transporter.

와 GLUT2 mRNA의 발현이 증가되어 있다는 보고가 있고[9] lean Zucker rat에 비해 obese Zucker rat에서 SGLT1과 SGLT2 발현이 증가되어 있었다[10]. 사람의 경우에도 정상인보다 제2형 당뇨병 환자에서 SGLT2와 GLUT2 발현이 증가되어 있고 신세뇨관에서의 포도당 흡수가 증가되었다는 연구가 있었다[11].

\section{SGLT2 억제제}

\section{SGLT2 억제제의 개발}

1835년에 사과나무의 뿌리껍질에서 비특이적 SGLT1와 SGLT2 억제제인 phlorizin이 처음으로 분리되었고 이것이 당 뇨(glucosuria)를 야기하여 혈당을 감소시키고 인슐린감수성 을 정상화시킨다고 알려졌다. 그러나 이 제제는 경구로 투여 하였을 때 흡수율이 낮고 위장관에 있는 SGLT1도 같이 억 제하기 때문에 glucose-galactose malabsorption과 설사를 야기

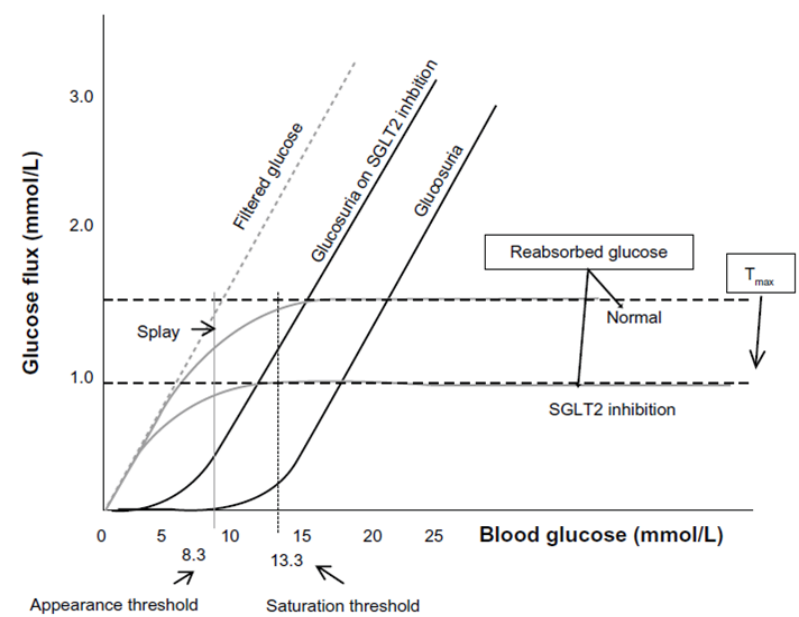

Figure 2. Renal glucose handling. SGLT, sodium-glucose cotransporter; $\mathrm{T}_{\max }$, transport maximum.

하여 당뇨병 치료제로 사용되기에는 부적절하였다. 이러한 단점을 보완하기 위해 SGLT2에 대한 특이성이 높은 억제제 를 개발하게 되었다. 그 중에서 dapagliflozin은 2012년 유럽 에서 승인을 받았고 2014년 미국 FDA에서도 승인을 받았으 며 2013년 11월 SGLT2 억제제 계열 약제들 중에서는 아시 아 국가 중에서 한국이 가장 처음으로 허가를 하였다. Canagliflozin은 2013년 미국 FDA의 승인을 받았으며 empagliflozine도 미국과 유럽에서 승인절차를 기다리는 중이다(Table 2).

\section{SGLT2 억제제의 임상연구 결과}

\section{Dapagliflozin}

Dapagliflozin $10 \mathrm{mg}$ 단독 또는 metformin, glimepiride, sitagliptin, pioglitazone 및 인슐린과의 병합요법에 대한 임상 연구들에서 당화혈색소는 $0.5 \%$ 에서 $0.8 \%$ 정도 감소하였다. 공복혈당은 평균 $17-33 \mathrm{mg} / \mathrm{dL}$ 감소하였고 식후 혈당 역시 
- 김미경 외 1인. Sodium glucose co-transporter 2 (SGLT2) 억제제 -

Table 2. Selected SGLT2 inhibitors in development (data from ClinicalTrials.gov)

\begin{tabular}{ll}
\hline Compound & \multicolumn{1}{c}{ Company } \\
\hline Dapagliflozin & Bristol-Myers Squibb and AstraZeneca \\
Canagliflozin & Johnson \& Johnson \\
Empagliflozin & Boehringer Ingelheim \& Eli Lilly \\
Ipragliflozin & Astellas \\
Tofogliflozin & Roche \& Chugai Pharmaceuticals \\
Luseogliflozin & Taisho Pharmaceuticals \\
Ertugliflozin & Pfizer \\
\hline
\end{tabular}

의미있게 감소되었다. 체중은 $2.5-3.2 \mathrm{~kg}$ 감소하였고 수축기 혈압은 2-9 $\mathrm{mmHg}$, 이완기 혈압도 $2 \mathrm{mmHg}$ 감소하였다. 평균 적으로 total cholesterol은 $1 \%$ 증가, $\mathrm{HDL}$ cholesterol은 $1.7 \%$ 증가, $\mathrm{LDL}$ cholesterol은 $0.8 \%$ 증가, 중성지방은 $4.7 \%$ 감소시 켰다[12-15]. 전체적으로는 약제에 대한 순응도는 좋았으 며 가장 흔한 부작용은 headache, diarrhea, back pain, upper respiratory tract infection 등이었는데 대조군과 의미 있는 차 이는 보이지 않았다. 특히 여성에서는 genital infection의 빈 도가 증가하였는데 위약군이 $1 \%$ 인데 반해 dapagliflozin군은 $4-6 \%$ 로 보고되었다. 하지만 중증도는 심하지 않아서 대부분의 경우 항생제 치료에 잘 반응하였다. Urinary tract infection도 약간 증가하는 경향을 보였다. 저혈당은 인슐린이나 glipmepiride와의 병합요법에서만 대조군에서보다 약간 증가하였 다. 10 명의 환자에서 방광암이 보고되었는데 대부분은 연구 시작 전에 이미 혈뇨가 있었던 환자였고 약제 사용 후 6 개월 이내에 발견되었으므로 약제 사용과 직접적인 연관성이 있 다고 하기는 어렵다. 신기능이 감소되어 있는 환자에서는 효 과가 적어 중등도 이상의 신 장애 환자에게는 권장되지 않 는다[12-15].

\section{Canagliflozin}

총 504 명의 환자들을 대상으로 26 주간 관찰한 연구에서 canagliflozin $100 \mathrm{mg}$ 을 사용한 군에서 당화혈색소가 기저치 에 비해 $0.77 \%$ 감소하였으며 위약군에 비해 공복혈당, 식후 혈당, 체중 및 혈압 등이 유의하게 감소하였다고 한다. 병용 요법에서도 유사한 결과를 보였다. Pooled analysis에서 LDL cholesterol이 4.5-8.0\% 정도 증가하였지만 심혈관 질환에 대 한 다른 위험인자들인 혈압, 체중 및 $\mathrm{HDL}$ cholesterol 등에는 좋은 영향을 보여주었다[16-19]. Dapagliflozin과 안정성 측면
에서는 큰 차이가 나지 않고 역시 제일 흔한 부작용은 female genital mycotic infection과 urinary tract infection이었다. 이뇨 효과 때문에 기립성저혈압이나 체위성 현훈, 갈증 및 탈수가 몇 증례에서 보고되었다. 현재 심혈관 합병증에 대해서는 Canagliflozin Cardiovascular Assessment Study (CANVAS)라는 대규모 임상연구가 국내를 포함해서 진행 중에 있다.

\section{결 론}

SGLT2 억제제는 기존의 당뇨병 약제와는 작용기전의 측 면에서 전혀 다른 약제로, 현재까지의 제 2 형 당뇨병 치료에 추가적으로 혈당강하 기능을 더할 수 있을 것으로 기대된다. 인슐린에 비의존적으로 작용하므로 당뇨병 환자의 베타세포 기능에 관계없이 작용할 수 있고 저혈당 발생의 위험성이 적다. 현재까지의 임상연구 결과들을 볼 때 단독 및 인슐린 을 포함한 여러 가지 약제들과의 병합요법에서 효과적인 추 가 혈당강하 효과를 보였으며 혈당강하 효과 외에 혈압 및 체중의 의미 있는 감소 등 당뇨병 치료의 전체적인 대사적 측면에서도 큰 장점이 있어 전체적인 합병증 감소에 의미 있는 이득을 줄 가능성이 높다고 사료된다. 가장 큰 단점은 genital infection과 urinary tract infection이 특히 위생상태가 좋지 않은 여성에게 늘어난다는 점이며 이 부분은 실제 임 상에서 사용된 이후 장기적으로 그 의미가 다시 평가되어야 할 것이다. 개발과정에서 우려가 되었던 방광암의 발생 위험 은 현재로서는 생물학적인 근거가 없는 것으로 잠정 결론이 되어 있지만 이 역시 임상에서 광범위하게 사용이 되면 반 드시 재평가가 필요할 수도 있을 것이다. 결론적으로 SGLT2 억제제의 등장은 기존의 당뇨병 치료방법에 더해 분명히 임 상적으로 의미가 있는 발전이라 판단되며 특히 심혈관 질환 에 대한 의미 있는 효과를 기대할 수 있을 것으로 본다.

중심 단어: 제2형 당뇨병; 신장 포도당 재흡수; SGLT2 억 제제; 요로 감염; 외부 생식기 감염

\section{REFERENCES}

1. Korean Diabetes Association. Diabetes Facts Sheets in Korea 2013. KDA, 2013

2. Gerich JE. Physiology of glucose homeostasis. Diabetes Obes Metab 2000;2:345-350. 
3. Meyer C, Dostou JM, Welle SL, Gerich JE. Role of human liver, kidney, and skeletal muscle in postprandial glucose homeostasis. Am J Physiol Endocrinol Metab 2002;282: E419-427.

4. Meyer C, Stumvoll M, Welle S, Woerle HJ, Haymond M, Gerich J. Relative importance of liver, kidney, and substrates in epinephrine-induced increased gluconeogenesis in humans. Am J Physiol Endocrinol Metab 2003;285:E819826.

5. Bakris GL, Fonseca VA, Sharma K, Wright EM. Renal sodium-glucose transport: role in diabetes mellitus and potential clinical implications. Kidney Int 2009;75:12721277.

6. Silverman M, Turner J. Glucose transport in the renal proximal tubule. In: Windhager EE, Ed. Handbook of Physiology. New York Oxford University Press, 1992:20172038.

7. Nair S, Wilding JP. Sodium glucose cotransporter 2 inhibitors as a new treatment for diabetes mellitus. J Clin Endocrinol Metab 2010;95:34-42.

8. Meyer C, Woerle HJ, Dostou JM, Welle SL, Gerich JE. Abnormal renal, hepatic, and muscle glucose metabolism following glucose ingestion in type 2 diabetes. Am J Physiol Endocrinol Metab 2004;287:E1049-1056.

9. Vestri S, Okamoto MM, de Freitas HS, et al. Changes in sodium or glucose filtration rate modulate expression of glucose transporters in renal proximal tubular cells of rat. J Membr Biol 2001;182:105-112.

10. Freitas HS, Anhê GF, Melo KF, et al. $\mathrm{Na}(+)$-glucose transporter-2 messenger ribonucleic acid expression in kidney of diabetic rats correlates with glycemic levels: involvement of hepatocyte nuclear factor-1alpha expression and activity. Endocrinology 2008;149:717-724.

11. Rahmoune H, Thompson PW, Ward JM, Smith CD, Hong G, Brown J. Glucose transporters in human renal proximal tubular cells isolated from the urine of patients with noninsulin-dependent diabetes. Diabetes 2005;54:3427-3434.

12. Kaku K, Inoue S, Matsuoka O, et al. Efficacy and safety of dapagliflozin as a monotherapy for type 2 diabetes mellitus in Japanese patients with inadequate glycaemic control: a phase II multicentre, randomized, double-blind, placebocontrolled trial. Diabetes Obes Metab 2013;15:432-440.

13. Bailey CJ, Gross JL, Pieters A, Bastien A, List JF. Effect of dapagliflozin in patients with type 2 diabetes who have inadequate glycaemic control with metformin: a randomised, double-blind, placebo-controlled trial. Lancet 2010;375: 2223-2233.

14. Nauck MA, Del Prato S, Meier JJ, et al. Dapagliflozin versus glipizide as add-on therapy in patients with type 2 diabetes who have inadequate glycemic control with metformin: a randomized, 52-week, double-blind, activecontrolled noninferiority trial. Diabetes Care 2011;34:20152022.

15. Wilding JP, Norwood P, T'joen C, Bastien A, List JF, Fiedorek FT. A study of dapagliflozin in patients with type 2 diabetes receiving high doses of insulin plus insulin sensitizers: applicability of a novel insulin-independent treatment. Diabetes Care 2009;32:1656-1662.

16. Stenlöf K, Cefalu WT, Kim KA, et al. Efficacy and safety of canagliflozin monotherapy in subjects with type 2 diabetes mellitus inadequately controlled with diet and exercise. Diabetes Obes Metab 2013;15:372-382.

17. Cefalu WT, Leiter LA, Yoon KH, et al. Efficacy and safety of canagliflozin versus glimepiride in patients with type 2 diabetes inadequately controlled with metformin (CANTATA$\mathrm{SU}): 52$ week results from a randomised, double-blind, phase 3 non-inferiority trial. Lancet 2013;382:941-950.

18. Schernthaner G, Gross JL, Rosenstock J, et al. Canagliflozin compared with sitagliptin for patients with type 2 diabetes who do not have adequate glycemic control with metformin plus sulfonylurea: a 52-week randomized trial. Diabetes Care 2013;36:2508-2515.

19. Yale JF, Bakris G, Cariou B, et al. Efficacy and safety of canagliflozin in subjects with type 2 diabetes and chronic kidney disease. Diabetes Obes Metab 2013;15:463-473. 